\title{
Determinan Penyerapan Tenaga Kerja Di Indonesia Tahun 2011-2015
}

\author{
(Determinant Of Labor Absorption In Indonesia In 2011-2015)
}

\author{
Dyan Prihatini*, Sunlip Wibisono, Regina Niken Wilantari \\ Jurusan Ilmu Ekonomi dan Studi Pembangunan, Fakultas Ekonomi dan Bisnis, Universitas Jember (UNEJ) \\ Jln. Kalimantan 37, Jember 68121 \\ E-mail: dyanprihatini11@gmail.com
}

\begin{abstract}
Abstrak
Penyerapan tenaga kerja adalah jumlah tertentu dari tenaga kerja yang diserap dan digunakan dalam suatu unit usaha tertentu untuk menjalankan proses produksi. Penyerapan tenaga kerja dipengaruhi oleh tingkat investasi, dan upah minimum tenaga kerja. Penetapan tingkat upah yang dilakukan pemerintah pada suatu wilayah akan memberikan pengaruh terhadap besarnya tingkat pengangguran yang ada. Semakin tinggi besarnya upah yang ditetapkan oleh pemerintah maka hal tersebut akan berakibat pada penurunan jumlah orang yang bekerja pada negara tersebut. Penelitian ini bertujuan untuk mengetahui pengaruh upah minimum provinsi, investasi dan tingkat pendidikan terhadap penyerapan tenaga kerja di Indonesia. Metode analisis yang digunakan dalam penelitian ini adalah metode analisis kuantitatif dengan regresi panel data (Pooled Least Squares). Hasil analisis dari penelitian ini adalah menunjukkan bahwa variabel upah minimum provinsi, investasi dan tingkat pendidikan memiliki pengaruh signifikan secara positif terhadap variabel penyerapan tenaga kerja.
\end{abstract}

Kata Kunci: Investasi, tenaga kerja, upah minimum provinsi, tingkat pendidikan, metode panel data.

\begin{abstract}
Labor absorption is a certain amount of labor that is absorbed and used in a particular business unit to run the production process. The absorption of labor is influenced by the level of investment, and the minimum wage of labor. Determination of the level of wages made by the government in a region will have an influence on the magnitude of the existing unemployment rate. The higher wages set by the government will result in a decrease in the number of people working in the country. This study aims to determine the effect of provincial minimum wages, investment and education levels on employment in Indonesia. The analytical method used in this study is a quantitative analysis method with panel data regression (Pooled Least Squares). The results of the analysis of this study are that the provincial minimum wage, investment and education level variables have a significant positive effect on the employment variable.
\end{abstract}

Keywords: Investment, labor, provincial minimum wage, education level, panel data method.

\section{Pendahuluan}

Pembangunan ekonomi merupakan serangkaian usaha dalam suatu perekonomian untuk mengembangkan kegiatan ekonominya sehingga infrastruktur lebih banyak tersedia. Tujuan pembangunan ekonomi yang dilakukan oleh setiap negara adalah untuk menciptakan pembangunan yang dapat dirasakan secara menyeluruh oleh setiap masyarakat, yakni dengan perusahaan semakin banyak dan berkembang, taraf pendidikan semakin tinggi dan teknologi meningkat. Sehingga pada gilirannya diharapkan kesempatan kerja bertambah, tingkat pendidikan meningkat dan kemakmuran masyarakat menjadi semakin tinggi sebagai akibat dari meningkatnya pendapatan masyarakat Sukirno (2006:3). Tenaga kerja adalah modal bagi geraknya roda pembangunan. Menurut Sukirno (2006:7) tenaga kerja bukan berarti jumlah buruh yangterdapat dalam perekonomian, tetapi tenaga kerja juga meliputi keahlian dan ketrampilan yang mereka miliki.

Pembahasan mengenai tenaga kerja berkaitan dengan kesempatan kerja. Kesempatan kerja dapat disebut juga dengan penyerapan tenaga kerja. Penyerapan tenaga kerja adalah jumlah tertentu dari tenaga kerja yang diserap dan digunakan dalam suatu unit usaha tertentu untuk menjalankan proses produksi. Penyerapan tenaga kerja dipengaruhi oleh tingkat investasi, dan upah minimum tenaga kerja. Adanya kesempatan kerja tersebut, akan memberikan kesempatan kepada masyarakat untuk melakukan kegiatan perekonomian yang menjadi sumber penghasilan untuk memenuhi kebutuhan hidupnya. Kesempatan kerja digunakan sebagai salah satu indikator untuk menilai keberhasilan pembangunan ekonomi suatu negara.Naik turunnya tingkat upah akan mempengaruhi biaya produksi. Kaitannya adalah apabila upah sedang mengalami kenaikan maka akan meningkatkan biaya produksi dikarenakan tenaga kerja memiliki motivasi untuk melakukan produksi yang lebih sehingga biaya produksi yang dikeluarkan oleh perusahaan akan tinggi, dengan adanya peningkatan biaya inilah akhirnya barang dan jasa yang dihasilkan akan meningkatkan harga per unit. Sehingga konsumen akan mulai mengurangi penggunaan barang atau jasa, akibatnya barang-barang atau jasa yang tidak terjual akan menurunkan target produksi yang akan berpengaruh juga terhadap pengurangan tenaga kerja.

Faktor lain yang dapat mempengaruhi penyerapan tenaga kerja adalah investasi. Investasi dilakukan dalam rangka penyediaan barang-barang modal seperti mesin dan perlengkapan produksi untuk meningkatkan hasil produksinya yang nantinya akan meningkatkan penyerapan tenaga kerja karena barang-barang tersebut membutuhkan tenaga manusia untuk mengoperasikannya. Sehingga semakin

\footnotetext{
* Corresponding author
} 
tinggi nilai investasi maka semakin tinggi pula tingkat penyerapan tenaga kerja. Investasi memiliki peran yang sangat penting dalam pembangunan ekonomi, khususnya untuk mendorong pertumbuhan ekonomi Mankiw (2003:279). Rumusan masalah yang terdapat dalam penelitian ini adalah seberapa besar Upah Minimum Propinsi, Investasi, dan Tingkat Pendidikan berpengaruh terhadap penyerapan Tenaga Kerja di Indonesia pada tahun 2011-2015.

\section{Metode}

\section{Jenis Penelitian}

Penelitian ini menggunakan explanatory dengan pendekatan kuantitatif, adalah jenis penelitian yang berfungsi untuk menjelaskan hubungan antara variabel dependen dan independen

\section{Jenis dan Sumber Data}

Data yang di gunakan dalam penelitian ini adalah data sekunder sebagai data utama.Data sekunder berupa data panel, yaitu data yang terdiri dari dua bagian : (1) time series dan (2)cross section. Data time series yang digunakan adalah data tahunan selama lima tahun yaitu tahun 2011-2015, sedangkan data cross section sebanyak tiga puluh tiga yang menunjukkan jumlah provinsi di Indonesia yang diteliti. Jenis data yang digunakan dalam penelitian ini adalah menggunakan data sekunder yang diperoleh dari Badan Pusat Statistik (BPS), dan jurnal online.

\section{Metode Analisis Data}

Pada penelitian ini digunakan metode:

\section{Analisis Panel Data}

Analisis regresi data panel (Pooled Least Squares) adalah mengkombinasikan antara analisis menggunakan time series dan cross section, Gujarati (2010).

model dapat ditulis sebagai berikut :

Yit $=x i t \beta i t+\varepsilon i t$

Dimana :

Yit $=$ Variabel yang dijelaskan

xit $=$ Variabel yang menjelaskan

$\beta$ it $=$ pengaruh dari perubahan dalam $X$

$\varepsilon$ it $=$ Kesalahan (disturbance term)

Dengan melihat model di atas sehingga faktor-faktor yang mempengaruhi penyerapan tenaga kerja di Indonesia dapat digambarkan dengan fungsi sebagai berikut :

PTKit $=\mathrm{f}($ UMPit + Invsit + TPit $)$

Dari persamaan fungsi diatas maka dapat ditransformasikan kedalammodel ekonometrika sebagai berikut :

PTKit $=\beta 0+\beta 1$ UMPit $+\beta 2$ Invsit $+\beta 3$ TPit $+\varepsilon i t$

Keterangan :

PTK $=$ Penyerapan Tenaga kerja(jiwa)

$\mathrm{UMP}=\mathrm{UMP}$ (ribuan rupiah)

Invs $=$ Investasi (milyar rupiah)

$\mathrm{TP}=$ Tingkat Pendidikan (jiwa)

$\mathrm{i}=$ Cross section (33 provinsi di Indonesia) $\mathrm{t}=$ Time series (2011-2015)

$\beta 0=$ Intercept

$\beta 1=$ Pengaruh UMP terhadap penyerapan tenaga kerja

$\beta 2=$ Pengaruh Investasi terhadap penyerapan tenaga kerja

$\beta 3=$ Pengaruh Pendidikan terhadap penyerapan tenaga kerja

$\varepsilon=$ Komponen error

Gambaran dari variabel-variabel tersebut adalah :

a. Variabel yang menjadi variabel dependent adalah penyerapan tenaga kerja. Penyerapan tenaga kerja(Y) adalah jumlah penduduk produktifdimasing-masing provinsi yang telah memiliki pekerjaan yang tinggaldi Indonesia dalam kurun waktu 2011-2015 dengan satuan jiwa pertahun.

b. Variabel yang menjadi variabel independent dalam penelitian ini meliputi :

1) Upah minimum provinsi (X1) adalah upah minimum yang ditetapkan dimasing-masing provinsi di Indonesia pada tahun 2011-2015 dengan satuan ribuan rupiah per tahun.

2) Investasi (X2) adalah realisasi investasi yang terdiri atas PMDN(Penanaman Modal Dalam Negeri) dan PMA (Penanaman ModalAsing) yang diterima dimasing-masing propinsi di Indonesia pada tahun 2011-2015 dengan satuan juta rupiah per tahun.

3) Tingkat pendidikan (X3) merupakan faktor penting bagi berhasilnya perkembangan ekonomi dan merupaka sumber daya yang terbesar manfaatnya jika dibanding faktor-faktor produksi lain. Dalam penelitian ini data yang digunakan adalah penduduk berusia 15 tahun ke atas menurut tingkat pendidikan pendidikan tertinggi yang ditamatkan yaitu pendidikan Sekolah Menengah Atas (SMA) di Indonesia tahun 2011-2015 dengan satuan jiwa/orang. Data Tingkat Pendidikan diperoleh dari publikasi online BPS dari tahun 2011-2015.

\section{Estimasi Regresi Data Panel}

a. Model Common Effect

Model Common Effect Model (CEM) adalah pendekatan model data panelyang paling sederhana karena hanya mengkombinasikan data time series dan cross section.

\section{b. Model Fixed Effect}

Metode Fixed Effect Model (FEM) mengasumsikan bahwa slope konstanakan tetapi intersep berbeda antara individu, menempatkan bahwa eit merupakan kelompok spesifik atau berbeda dalam constat term pada model regresi. Bentuk model tersebut biasanya disebut model least squares dummy variable (LSDV).

\section{c. Model Random Effects}

Model efek acak, meletakkan $\alpha$ i sebagai gangguan spesifik kelompok seperti halnya eit kecuali mentapkan untuk tiaptiap kelompok, tetapi gambaran tunggal yang memasukkan regresi sama untuk tiap-tiap periode, atau dengan kata lain Random Effect Model (REM) menganggap bahwa seluruh gangguan yang terjadi mempunyai sifat acak atau random.

\section{Uji Model Data Panel}

a. Uji Chow 
Uji Chow dilakukan untuk mengetahui model yang terbaik antara common effect dengan fixed effect digunakan signifikasi Chow. Dalam pengujian ini dilakukan dengan hipotesis sebagai berikut :

\section{H0 : Model Common Effect}

\section{H1 : Model Fixed Effect}

Kriteria pengujiannya adalah sebagai berikut :

1. Jika Chow Statistif ( $F$ - statistic) $>\mathrm{F}$ tabel, maka H0 ditolak dan lebih menggunakan FEM (fixed effect method)

2. Jika Chow Statistif (F- statistic) $<\mathrm{F}$ tabel, maka H1 ditolak dan lebih menggunakan CEM (common effect method)

\section{b. Uji Hausman}

Uji signifikansi Hausman menggunakan uji hipotesis berbentuk $\mathrm{H} 0: \mathrm{E}(\mathrm{Ci} \mid \mathrm{X})=\mathrm{E}(\mathrm{u})=0$, atau adanya efek acak di dalam model. Jika H0 ditolak maka model efek akan tetap digunakan.

Pengujian hipotesanya adalah sebagai berikut (Futurrohmin,2011:60):

\section{H0 : Model Random Effect}

H1 : Model Fixed Effect

Kriteria pengujiannya adalah sebagai berikut :

1. Jika Chi-Square statistic >Chi-Square table, maka H0 ditolak dan lebih menggunakan FEM (fixed effect methode)

2. Jika Chi-Square statistic $<$ Chi-Square table, maka H0 diterima dan lebih menggunakan REM (random effect methode).

\section{Uji Statistik}

\section{Uji-F (Secara Simultan)}

Menurut Mulyono (2005) Uji signifikasi secara simultan merupakan uji hipotesa secara gabungan atau serentak untuk mengetahui hubungan antara X1 dan X2 maupun X3 terhadap variabel $\mathrm{Y}$. Dengan kriteria apabila probabilitas Fhitung lebih besar dari level of significance $(\alpha=0,05)$ maka UMP, Investasi dan Tingkat Pendidikan tidak nyata secara bersama-sama berpengaruh terhadap penyerapan tenaga kerja. dan apabila probabilitas $\mathrm{F}$ hitung lebih kecil dari level of significance $(\alpha=0,05)$ maka UMP, Investasi dan Tingkat Pendidikan berpengaruh secara nyata terhadap penyerapan tenaga kerja.

\section{Uji-t (Secara Parsial)}

Menurut Mulyono (2005) Uji t digunakan untuk mengetahui seberapa jauh seuatu variabel independent (individu) secara parsial mempengaruhi variabel dependent. Dengan kriteria jika nilai $\mathrm{t}$ hitung lebih kecil daripada nilai $\mathrm{t}$ tabel berdasarkan nilai level of significance $(0,05)$ maka hipotesis nol (H0) diterima dan Ha ditolak. Dan jika nilai t hitung lebih besar daripada nilai $\mathrm{t}$ tabel berdasarkan nilai level of significance $(0,05)$ maka hipotesis nol $(\mathrm{H} 0)$ ditolak dan $\mathrm{Ha}$ diterima. Dalam penelitian ini digunakan uji one tailed, yakni pengujian hipotesis yang sudah diketahui arah positif maupun negatifnya.

Hipotesis pengujian uji $\mathrm{t}$ adalah :
$\mathrm{H} 0: \beta 1=0$

$\mathrm{Ha}: \beta 1 \neq 0$

Artinya apabila $\beta 1$ sama dengan nol, maka variabel independen tidak mempunyai pengaruh yang signifikan terhadap variabel dependen. Sedangkan apabila $\beta 1$ tidak sama dengan nol, maka variabel independen mempunyai pengaruh yang signifikan terhadap variabel dependen.

\section{Uji Asumsi Klasik}

\section{Uji Multikolinearitas}

Menurut Ghozali (2007:91) uji multikolinearitas bertujuan untuk menguji apakah model regresi ditemukan adanya korelasi antar variabel bebas (independen). Model yang baik seharusnya tidak terjadi korelasi di antara variabel independen. Uji multikolinearitas digunakan untuk mengetahui apakah antar variabel independen saling mempengaruhi ataukah tidak, apabila variabel independen saling mempengaruhi, maka akan menyebabkan nilai standar deviasi menjadi semakin tinggi dan nilai terkecil sehingga data tidak akan signifikan. Sehingga data akan dikatakan baik apabila data tersebut tidak mengandung multikol untuk mendeteksi ada mutikolinearitas di dalam model regresi adalah sebagai berikut :
a. Nilai R2 lebih tinggi
b. Nilai t dari semua variabel bebas tidak signifikan
c. Tingginya nilai $\mathrm{f}$

\section{Uji Heteroskedastisitas}

Menurut Ghozali (2007:105) uji heteroskedastisitas bertujuan mengujiapakah dalam model regresi terjadi ketidaksamaan variance dari residual satupengamatan ke pengamatan yang lain. Model regresi yang baik adalah modelyang homoskedastisitas (tidak terjadi heterokedastisitas).

Dalam penelitian ini untuk mendeteksi ada tidaknya heteroskedastisitas dapat dilakukan dengan Uji Park yakni dengan cara meregres dari log residual yang dikuadratkan dengan variabel dependennya. Kriterianya jika t-statistik lebih besar daripada t-tabel (t-statistik $>$ t-tabel) atau nilai probabilitasnya kurang dari sama dengan 0,05 (prob $\leq 0,05$ ) maka di indikasikan terjadi adanya heteroskedastisitas. Namun jika t-statistiknya kurang dari t-tabel (t-statistik $<\mathrm{t}$ tabel) atau nilai probabilitasnya lebih besar dari 0,05 (prob $>$ $0,05)$ maka tidak terjadi adanya heteroskedastisitas.

\section{Uji Autokorelasi}

Menurut Ghozali (2007:96) uji autokorelasi bertujuan untuk menguji apakah dalam model regresi linier ada korelasi antara kesalahan pengganggu pada periode $t$ dengan kesalahan pengganggu pada periode t-1 (sebelumnya). Jika dalam model regresi terdapat korelasi, maka dinamakan ada autokorelasi. Cara yang digunakan untuk mendeteksi ada atau tidaknya autokorelsi pada sebuah model regresi adalah dengan uji Durbin-Watson (DW test). Uji DW digunakan untuk autokorelasi tingkat satu dan mensyaratkan adanya intersept dan model regresi tidak ada variabel lagi diantara variabel independen. Hipotesis dalam pengujian autokorelasi adalah:

H0 : tidak ada autokorelasi $(\mathrm{r}=0)$ 
$\mathrm{H} 1$ : ada autokorelasi $(\mathrm{r} \neq 0)$

\section{Uji Normalitas}

Menurut Ghozali (2007:100) uji normalitas bertujuan untuk mengujiapakah dalam model regresi, variable pengganggu atau residual memilikidistribusi normal. Ada dua cara untuk mendeteksi apakah residual berdistribusinormal atau tidak yaitu analisi grafik dan uji statisfik. Untuk mengukur kenormalan maka dilakukan penghitungan nilai Chi-square dan didasarkan test of skewness dan kurtosis of residual, dasar pengambilankeputusannya adalah sebagai berikut:

a. Apabila nilai Cs-hitung $>$ dari nilai Cs-tabel maka variabel pengganggu dari model adalah tidak normal.

b. Apabila nilai Cs-hitung < dari nilai Cs-tabel maka variabel pengganggu dari model adalah normal.

\section{Hasil dan Pembahasan}

\section{Hasil analisis}

Dalam penelitian ini analisis dilakukan pada sejumlah data time series dan data cross section yaitu sebanyak 33 sampel dari sejumlah provinsi di Indonesia pada periode tahun 20112015. Analisis data panel dilakukan dengan melakukan pemilihan metode yang tepat dalam menganalisis data-data hasil penelitian, metode tersebut yaitu common effect, fixed effect, dan random effect. Diantara ketiga metode analisis data panel tersebut akan dipilih salah satu metode yang selanjutnya akan digunakan untuk tahap uji statistik. Hasil dari perhitungan deskriptif dari setiap variabel akan dijelaskan dalam analisis deskriptif, dan akan dijelaskan beberapa hasil uji statistik deskriptif, OLS yang bertujuan untuk melihat pengaruh dari Upah Minimum Provinsi, Investasi dan Tingkat Pendidikan terhadap Penyerapan Tenaga Kerja di Indonesia. Penjelasan hasil estimasi yang telah diuraikan sebelumnya dapat disimpulkan bahwa berdasarkan variabel yang diamati yaitu Penyerapan Tenaga Kerja, Upah Minimum Provinsi, Investasi dan Tingkat Pendidikan di Indonesia masing-masing memiliki gejolak pergerakan yang relatif bervariasi. Uji Chow dilakukan untuk mengetahui model yang terbaik antara common effect dengan fixed effect.

Berdasarkan hasil uji chow dapat diinterprestasikan bahwa nilai $F$ statistic diperoleh sebesar 693.150800, atau lebih besar daripada nilai $F$ table, yakni $(32,128)$. Maka dapat dinyatakan bahwa $\mathrm{HO}$ ditolak dan lebih menggunakan Fixed Effects Methode (FEM). Uji Hausman dilakukan untuk mengetahui model yang terbaik antara fixed effect dengan random effect. Berdasarkan uji hausman di atas dapat diinterprestasikan bahwa nilai Chi-Suare statistic diperoleh sebesar 160.345545, atau lebih besar daripada nilai ChiSuare table, yakni 3. Dengan nilai probabilitas sebesar 0.0000 atau lebih rendah dari $\alpha=0,05$. Maka dapat dinyatakan bahwa $H O$ ditolak dan lebih menggunakan Fixed Effects Methode (FEM). Berdasarkan uji hausman sebelumnya, diketahui bahwa model paling tepat adalah menggunakan Fixed Efect Methode (FEM). Berdasarkan tabel 4.9 dapat diperoleh persamaan model sebagai berikut :

PTKit=3007912+0.174489UMPit+0.910521 Invsit + $0.646885 \mathrm{TPit}+$ eit

Dari model diatas dapat dijelaskan bahwa :
1. Nilai koefisien penyerapan tenaga kerja sebesar 3007912 orang artinya penyerapan tenaga kerja sebesar 3007912 orang apabila variabel upah minimum provinsi, investasi dan tingkat pendidikan diasumsikan bersifat konstan.

2. Pengaruh UMP terhadap penyerapan tenaga kerja adalah sebesar 0.174489 artinya apabila UMP naik sebesar Rp. 100.000 maka akan menaikkan penyerapan tenaga kerja sebesar 17448,9 orang.

3. Pengaruh investasi terhadap penyerapan tenaga kerja adalah sebesar 0.910521 artinya apabila investasi naik sebesar Rp. 1.000.000.000 maka akan meningkatkan penyerapan tenaga kerja sebesar 910.521 .000 orang.

Pengaruh tingkat pendidikan terhadap penyerapan tenaga kerja adalah sebesar 0.646885 orang artinya apabila tingkat pendidikan naik sebesar $1 \%$ maka akan meningkatkan penyerapan tenaga kerja sebesar $0.646885 \%$. Berdasarkan hasil analisis uji f, menunjukkan bahwa nilai probabilitas Fstatistik sebesar 0.000000 yang berarti nilai tersebut lebih kecil dari tingkat signifikansi $(\alpha=0,05)$ sehingga hipotesis nol (H0) ditolak dan hipotesis alternatif (Ha) diterima. Hal ini menunjukkan bahwa variabel upah minimum provinsi (UMP), investasi (Invst) dan tingkat pendidikan (TP) secara simultan mempunyai pengaruh yang signifikan terhadap variabel penyerapan tenaga kerja (PTK) di Indonesia. Uji t digunakan untuk mengetahui seberapa jauh suatu variabel independen (individu) secara parsial mempengaruhi variabel dependen. Tabel distribusi t dicari pada $\alpha=5 \%$ dengan derajat kebebasan (df) $\mathrm{n}-\mathrm{k}-1$ atau $164-3-1=160$. Berdasarkan hasil analisis uji t, diketahui bahwa besarnya masing-masing pengaruh variabel adalah sebagai berikut :

1. Variabel UMP memiliki nilai t $3.888558>1.654433$ dan nilai signifikansi $0,00<0,05$, maka H0ditolak Ha diterima, yang berarti secara parsial variabel UMP berpengaruh signifikansi terhadap penyerapan tenaga kerja di Indonesia.

2. Variabel Investasi memiliki nilai t $2.927437>1.654433$ dan nilai signifikansi $0.00<0,05$, maka $\mathrm{H} 0$ ditolak dan Ha diterima, yang berarti secara simultan variabel Investasiberpengaruh signifikansi terhadap penyerapan tenaga kerja di Indonesia.

Variabel Tingkat Pendidikan memiliki nilai t $0.328116<$ 1.654433 dan nilai signifikansi $0,00<0,05$, maka H0 ditolak dan Ha diterima, yang berarti secara parsial variabel Tingkat Pendidikan tidak berpengaruh signifikansi terhadap penyerapan tenaga kerja di Indonesia. Koefisien determinasi berganda merupakan suatu ukuran kesesuaian garis regresi terhadap adanya data yang dipakai dalam penelitian, atau menunjukkan proporsi dari variabel terikat dengan variabel independen yang berfungsi untuk menjelaskan variabel dependen, atau dengan kata lain untuk mengukur seberapa besar kemampuan model dalam menerangkan variasi variabel dependen. diperoleh hasil koefisien determinasi berganda (R2) sebesar 0.999105, hal ini berarti 99\% tingkat penyerapan tenaga kerja di Indonesia dipengaruhi oleh variabel upah minimum, investasi dan tingkat pendidikan, dan sisanya $1 \%$ dipengaruhi oleh variabel lainnya diluar model penelitian. Uji multikolinearitas bertujuan untuk menguji apakah model regresi ditemukan adanya korelasi antar variabel independen. 
Berdasarkan uji multikolinearitas, menunjukkan bahwa nilai korelasi antara semua variabel independen tidak lebih dari 0,8 Sehingga dapat dikatakan bahwa dalam model tersebut tidak terdapat gejala multikolinearitas. Uji heteroskedastisitas bertujuan menguji apakah dalam model regresi terjadi ketidaksamaan variance dari residual satu pengamatan ke pengamatan yang lain. Model regresi yang baik adalah model yang homoskedastisitas (tidak terjadi heteroskedastisitas). Kriteria yang digunakan adalah nilai probabilitas semua variabel lebih besar dari pada nilai $\alpha \mathrm{n}(\alpha=0.05)$. Dalam penelitian ini untuk mendeteksi ada tidaknya heteroskedastisitas dapat dilakukan dengan Uji Park yakni dengan cara meregres dari residual yang dikuadratkan dengan variabel dependennya. Berdasarkan hasil analisis uji park, menunjukkan bahwa semua nilai probabilitas pada semua variabel lebih besar daripada nilai $\alpha(\alpha=0.05)$ sehingga di dalam model tidak terjadi masalah heteroskedastisitas.

Uji autokorelasi bertujuan untuk menguji apakah dalam model regresi linier ada korelasi antara kesalahan pengganggu pada periode $\mathrm{t}$ dengan kesalahan pengganggu pada periode t-1 (sebelumnya). Cara yang digunakan untuk mendeteksi ada atau tidaknya autokorelsi pada sebuah model regresi adalah dengan uji Durbin-Watson (DW test). Hasil regresi data panel metode fixed effectnilai Durbin-Watson (lihat tabel 4.9) yaitu sebesar sebesar 0.527677. Pada taraf signifikansi 5\% (0.05) dengan jumlah observasi sebesar 164 dan jumlah variabel 4, pada DW tabel diperoleh nilai dL sebesar 1.70754dan du sebesar 1.78198. Nilai DW statistik berada pada area $0<\mathrm{d}<\mathrm{dL}$ yaitu $0<0.527677<1.70754$. Hal ini menunjukkan bahwa H0 ditolak yang artinya ada autokorelasi positif. Pengujian normalitas pada penelitian ini dilakukan melalui uji Jarque-Berra dengan perhitungan skewness dan kurtosis. Keputusan suatu model dikatakan terdistribusi normal atau tidak dapat dilihat pada probabilitas Jarque Berra. Apabila nilai Jarque-Bera kurang dari 2 dan nilai probabilitas lebih dari 5\%, maka dapat dikatakan bahwa model tersebut berdistribusi normal. Berdasarkan hasil uji normalitas, menunjukkan bahwa nilai Jarque-Berra sebesar 0.339596 kurang dari2, dan nilai probabilitas sebesar 0.843835 lebih besar dari 0,05. Maka dapat dikatakan bahwa model tersebut terdistribusi normal.

\section{Pembahasan}

Penelitian ini menggunakan metode analisis kuantitatif dengan regresi data panel dengan pendekatan fixed effect method (FEM). Berdasarkan hasil analisis, ditemukan adanya hubungan antara UMP, investasi dan tingkat pendidikan terhadap penyerapan tenaga kerja di Indonesia. Dimana UMP memberikan pengaruh yang signifikan secara positif terhadap penyerapan tenaga kerja di Indonesia, investasi dan tingkat pendidikan juga diketahui memberikan pengaruh yang signifikan secara positif terhadap penyerapan tenaga kerja di Indonesia. Berdasarkan hasil analisis uji statistik yang terdiri dari uji-f, uji-t, dan koefisien determinasi berganda (R2), dapat dijelaskan sebagai berikut. Dengan menggunakan pendekatan fixed effect method, ditemukan hasil pengujian simultan (uji-f) menunjukkan angka probabilitas sebesar 0.000000 lebih kecil dari tingkat signifikansinya yaitu sebesar 0,05 , sehingga dapat dikatakan bahwa upah minimum provinsi dan investasi secara bersama-sama memberikan pengaruh yang signifikan terhadap penyerapan tenaga kerja di Indonesia. Pada pengujian parsial (uji-t), dapat diketahui pengaruh UMP, investasi dan tingkat pendidikan secara individu berpengaruh signifikan terhadap penyerapan tenaga kerja di Indonesia. Dari hasil analisis dapat diketahui bahwa UMP menunjukkan angka probabilitas sebesar 0.000000 lebih kecil dari tingkat signifikansinya yaitu $0.05(\alpha=5 \%)$, sedangkan nilai koefisiennya sebesar 0.174489 Artinya variabel UMP mempunyai pengaruh yang signifikan positif terhadap tingkat penyerapan tenaga kerja di Indonesia, dan apabila UMP naik sebesar Rp 100.000 maka akanmenaikkan penyerapan tenaga kerja sebesar 17.448,9 orang. Hasil analisis menunjukkan bahwa UMP memberikan pengaruh yang signifikan positif terhadap penyerapan tenaga kerja di Indonesia. Fakta ini tidak sesuai dengan yang dijelaskan oleh Suryahadi (2002), dimana dijelaskan bahwa upah minimum memiliki pengaruh yang signifikan negatif terhadap penyerapan tenaga kerja. Hal ini disebabkan karena apabila terjadi kenaikan upah, maka berpotensi untuk menurunkan penyerapan tenaga kerja, terutama tenaga kerja yang produktivitasnya rendah. Sehingga kenaikan upah hanya mmeberikan pengaruh yang positif terhadap tenaga kerja yang memiliki produktivitas yang tinggi. Namun menurut penelitian Akmal (2010), upah minimum memberikan pengaruh yang signifikan positif terhadap penyerapan tenaga kerja. Peningkatan upah minimum secara otomatis akan meningkatkan penyerapan tenaga kerja. Hasil analisis uji-t pada variabel investasi, menunjukkan nilai probabilitas sebesar 0.0000 lebih kecil dari tingkat signifikansi $0.05(\alpha=$ $5 \%$ ), sedangkan nilai koefisiennya sebesar 0.910521. Artinya variabel investasi mempunyai pengaruh yang signifikan positif terhadap tingkat penyerapan tenaga kerja di Indonesia.Berdasarkan hasil penelitian menunjukkan bahwa investasi memberikan dampak yang signifikan positif terhadap penyerapan tenaga kerja di Indonesia, mengindikasikan bahwa setiap terjadi kenaikan investasi baik PMA maupun PMDN mempengaruhi daya serap tenaga kerja. Hasil analisis uji-t pada variabel tingkat pendidikan, menunjukkan nilai probabilitas sebesar 0.0000 lebih kecil dari tingkat signifikansi $0.05(\alpha=5 \%)$, sedangkan nilai koefisiennya sebesar0.646885. Artinya variabel tingkat pendidikan mempunyai pengaruh yang signifikan negatif terhadap tingkat penyerapan tenaga kerja di Indonesia. Berdasarkan hasil penelitian menunjukkan bahwa tingkat pendidikan tidak berpengaruh signifikansi dalam peningkatan penyerapan tenaga kerja.Hasil ini menunjukkan adanya tidak kesusaian dengan hipotesis yang telah dijelaskan oleh peneliti dalam penelitian ini.

\section{Simpulan}

Hasil analisis yang telah diperoleh pada bab sebelumnya akan digunakan untuk memberikan alternatif dalam pengambilan kebijakan oleh pemerintah untuk diterapkan dalam perekonomian Indonesia, khususnya dalam hal penyerapan tenaga kerja di Indonesia. Kesimpulan yang dapat diambil setelah melakukan penelitian ini melalui perbandingan dari teori, empiris dan hasil analisis menggunakan metode analisis kuantitatif dengan regresi data panel, adalah sebagai berikut :

1. Berdasarkan hasil analisis diketahui bahwa variabel UMP memiliki pengaruh siginifikan terhadap penyerapan tenaga kerja di Indonesia. Diketahui bahwa hasil regresi tidak sesuai dengan hipotesis awal yang menyatakan bahwa UMP berpengaruh negatif terhadap penyerapan tenaga kerja di Indonesia. Hasil ini sesuai dengan data empiris yang 
menunjukkan pada tahun 2011-2015 penyerapan tenaga kerja terus meningkat seiring dengan peningkatan upah minimum.

2. Berdasarkan hasil analisis diketahui bahwa variabel Investasi memiliki pengaruh terhadap signifikan penyerapan tenaga kerja di Indonesia. Setiap terjadi kenaikan penerimaan, investasi baik PMA dan PMDN, akan meningkatkan penyerapan tenaga kerja. Dikarenakan setiap adanya tambahan investasi, dibutuhkan tenaga kerja untuk mengelola investasi tersebut, sehingga peningkatan investasi akan menciptakan peluang usaha baru bagi tenaga kerja yang belum terserap di pasar tenaga kerja. Diketahui bahwa hasil regresi sesuai dengan hipotesis awal yang menyatakan bahwa investasi berpengaruh positif terhadap penyerapan tenaga kerja di Indonesia.

3. Berdasarkan hasil analisis diketahui bahwa variabel pengaruh yang signifikan terhadap penyerapan tenaga kerja di Indonesia. Tingkat pendidikan di Indonesia tidak mengalami peningkatan yang signifikan terutama pada tingkat SMA. Ini dikarenakan tingkat SMA tidak lebih fleksibel dari tingkat sarjana dalamsektor industri, perdagangan, dan jasa dengan komposisi yang cukup besar.

\section{Saran}

Berdasarkan hasil penelitian ini menunjukkan bahwa UMP, Investasi dan Tingkat Pendidikan memiliki peran penting dalam meningkatkan penyerapan Tenaga Kerja di Indonesia. Tenaga kerja merupakan indikator dalam pembangunan yang berarti faktor penggerak dalam pembangunan. Terdapat beberapa saran sebagai arahan ke depan dari peneliti agar penyerapan tenaga kerja dapat ditingkatkan, yaitu agar pemerintah dapat memperhatikan upah minimum agar dalam penetapannya tidak merugikan pengusaha atau tenaga kerja. Saran bagi pengusaha agar dapat memanfaatkan penetapan upah untuk mengelola keuangannya agar dapat dijadikan acuan membuka lapangan pekerjaan baru, dan bagi tenaga kerja, agar terus meningkatkan produktivitas kerjanya, sehingga dapat menguntungkan perusahaan.

Saran untuk pemerintah, dapat meningkatkan daya tarik wilayah di Indonesia agar mampu menarik investor untuk meningkatkan investasinya, lalu perlu adanya promosi daerah agar menarik investor asing untuk menanamkan modalnya.

Saran bagi pemerintah, agar lebih memperhatikan penduduk tingkat pendidikan SMA agar mendapatkan pekerjaan di tingkatnya dan lebih ail lagi jika diberi meningkatkan tingkat upah minimum yang diterima serta bagi penduduk tingkat pendidikan SMA untuk meningkatkan skill agar lebih banyak perusahaan yang dapat membuka lebar pekerjaan setingkat SMA.

\section{Referensi}

Akmal, R. (2010). Analisis Faktor-Faktor yang Mempengaruhi Penyerapan Tenaga Kerja di Indonesia.

Ghozali, I. (2007). Aplikasi Analisis Multivariate Dengan Program SPSS. BP Universitas Diponogoro.

Mankiw, N. G. (2003). Teori Makroekonomi (5. Terjema). Erlangga.

Mulyono. (n.d.). Statistika Untuk Ekonomi. Lembaga PenerbitFakultas Ekonomi Indonesia Universitas Indonesia.

N., D., \& Gujarati. (2010). Dasar dasar ekonometrika. Salemba Empat.

Sukirno. (2006). Mikro Ekonomi Teori Pengantar (3rd ed.). Rajagrafindo Persada.

Suryahadi. (2002). Upah dan Tenaga Kerja: Dampak Kebijakan Upah Minimum Terhadap Penyerapan Tenaga Kerja di Sektor Formal Perkotaan. 